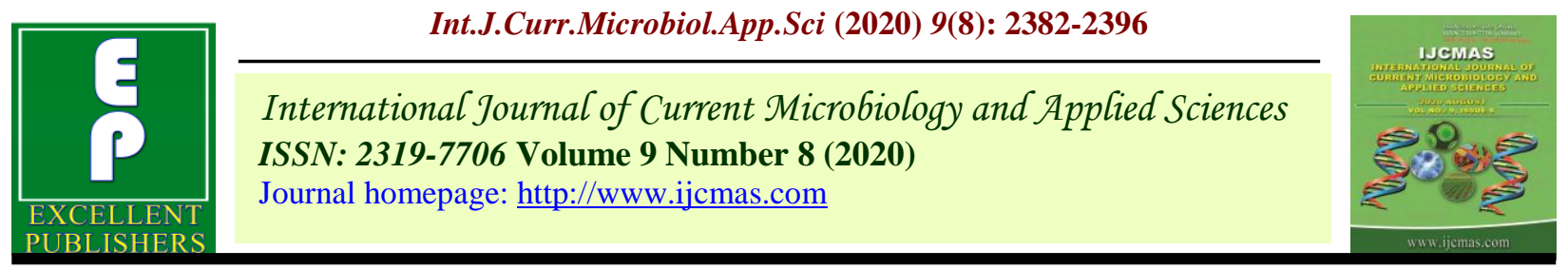

Original Research Article

https://doi.org/10.20546/ijcmas.2020.908.273

\title{
Response of Boron, Copper, Zinc Nitrogen, Phosphorus and Potassium on Some Growth Qualities of maize (Zea mays L.) Plant
}

\author{
M.L. Bubarai*, T. Thomas and N. Swaroop \\ Department of Soil Science and Agricultural Chemistry, Samhiggin Bottom University of \\ Agriculture Science and Technology, India \\ *Corresponding author
}

\begin{tabular}{|l|}
\hline Ke y w o r d s \\
Boron, Copper, \\
Zinc and NPK \\
\hline Article Info \\
\hline $\begin{array}{l}\text { Accepted: } \\
\text { 20 July } 2020 \\
\text { Available Online: } \\
10 \text { August } 2020\end{array}$ \\
\hline
\end{tabular}

\section{A B S T R A C T}

To study the response of Boron, Copper, Zinc, and NPK to the quality parameters of maize plant a field experiment was set up at Samhiggin Bottom University of Agriculture Science and Technology Prayagraj for two consecutive periods (2017 to 2018). The treatments consisted of $0,3,6,9 \mathrm{~kg}$ of Boron, zinc, copper $/ \mathrm{ha}$, and 0,50 and $100 \mathrm{kgNPK} / \mathrm{ha}$ respectively, and were arranged in a completely randomized design and replicated three times. Soil samples were collected from the field for routine analysis before planting. Plant parameters that were investigated include number of leaves which was obtained by counting, nutrients concentration in stems and leaves which were analyzed after samples were collected oven-dried and ground into powdered form. Grain yield and stover were also determined during harvest. The outcome of the investigations yielded a significant impact of the fertilizers on plant height, the number of leaves, concentrations of nutrients in plant parts and Yields of maize crop. The application of $100 \mathrm{kgNPK}+9 \mathrm{Kg} \mathrm{B}, \mathrm{Zn} \mathrm{Cu} \mathrm{ha}{ }^{-1}$ produces the best result. It is therefore advisable to incorporate micronutrients whenever major nutrients are added to crops to obtained maximum yield

\section{Introduction}

Maize or corn (Zea mays L) is a crop which belonging to the family of grasses (Poaceae). Maize is cultivated almost everywhere around the world. It is one of the most staple cereal crops especially in Africa. It has immense potential in the tropics and great yield can be obtained if the crop is properly managed. It is also an important feed and fodder to livestock and also a source of raw materials to many industries around the globe. It has been widely reported that maize has the capacity to produce good quantity of biomass under a very good integrated management condition (Chaudhary et al., 2012). Industrially the products which are obtained when maize is use as a source of raw materials include corn starch, maltodextrins, corn oil, corn syrup and products of fermentation and distillation. In 
the highly advanced countries the crop is harnessed to produce an alternative source of fuel. Maize is a crop which is capable of being cultivated over a wide range of agro climatic conditions. It has the unique characteristics to out with other crops to adapt to various agro climatic zones. Despite all this attributes the output is still very low, $5 \mathrm{t} / \mathrm{ha}$ (FAO. 2007) this has created some lapses of maize for its various usages. Some of the set back which affect the yield of maize crop is low return of nutrients to the soil after it has been depleted as a result of cultivation, also due to the inherent nature of the soil which is low in nutrients status especially in the developing community (FAO. 2007). This phenomena hindered maize production as maize has a strong exhausting effect on the soil. It was generally observed by research that maize fail to produce good grain in plots without adequate nutrients (Adediran and Banjoko, 2003). It has been observed that the used of inorganic fertilizer has a profound effect on yield and yield attributes of cereals crops more especially maize (Stefano et al., 2004). The following researchers (Fashina et al., 2002., Saeed et al., 2000 and Obi et al., 2005)observed that application of inorganic fertilizer accelerate rapid cell division and multiplication which leads to rapid growth, development and production of dry matter owing to better utilization of solar radiation and more nutrient. Therefore maize crop needs sufficient uptake of nutrients from soil especially the macronutrients NPK and some micronutrients like boron, zinc copper in smaller amount for good growth and high yields. The macronutrients in combination with minute's amount of boron, copper and zinc are capable of improving the quality of maize in all aspects.

Boron is micronutrients necessary for the development and metabolism of plants. It is an essential micronutrient, but it becomes toxic if used slightly above the critical level.
It is necessary for the correct growth, development and production of healthy vegetables in plants. It is associated with the introduction and development of growth points, the transport of nutrients within the plant, the formation of plant hormones that affect growth, root growth and the health of fleshy roots, the collection of flowers and fruits and the quality and taste of vegetables. It also contributes to disease resistance, cell division, pollen germination and pollen growth, B also aids in the movement of sugars and starch in developing parts. Boron also affects the colonization of mycorrhizae on the surface of the root and, therefore, affects the absorption of $\mathrm{P}$ (and also of $\mathrm{K}$ ). It also regulates the $\mathrm{K} / \mathrm{Ca}$ ratio in plants. Symptoms of $\mathrm{B}$ deficiency include decomposition of meristematic tissue and abnormalities of the reproductive organs. Low-B plants can produce distorted flowers, broken seeds, thick, fragile, wrinkled leaves or dead spots of growth (Brady and Weils, 1999). Boron deficiency can limit the development of leaves and roots and limit the growth of plants (Blevins and Łukaszewski, 1998). Corn boron deficiency reduces marginal defects and inflorescence, as well as vegetative defects (Durbark et al., 2014).A deficiency can also cause infertility to pollen and thus increase the risk of ergot in cereals. On the other hand, excessive concentrations are phytotoxic and can cause chlorotic and necrotic changes of the leaves. Accumulation of this element in plant tissues at high concentrations can cause leaf death and even death of the whole plant (Nable et al., 1997).

Copper is necessary for the development of the crop and the normal growth of cereal crops, and the absence and excess of copper inhibits the growth and production of crops (Jain et al., 2009). Yruela (2009) reported that copper helps in synthesis of food, breathing, series of electrons movement, ethylene identification and cell wall reactions in 
advanced plant. Copper plays a task in signaling transcription and protein trafficking machinery, iron mobilization and organic process at the cellular level of plants (Yruela, 2005). Monni et al., (2000) observed that Copper role within the biological system is as an intergral structural component; despite that the occurrence of copper in higher concentrations could result to a stress factor that limit plant growth, attachment of metals to sulf hydryl groups in proteins, and may disrupt the structure and restrain protein movement (Morelli and Scarano, 2004). Application of $\mathrm{Cu}$ increases the dry weight of the plant (Fageria and Kumar, 2002; Mathad and Pratima, 2009).

Zinc is a micronutrient element which is needed by higher plants, and its significant in agriculture is highly recognized (Genc et al., 2006). Small amount of Zinc is found in various soils over the globe, and the deficiency of Zinc may result to fewer yields in crop y (Cakmak et al., 1996; Rengel and Graham, 1995). Fageria et al., (2002) are of the view that the deficiencies of micronutrients zinc affect the global production of agricultural grain and its quality.

The lack of zinc is an important major factor which is affecting human health in the less developed countries of the world (Anthony et al., 2002). In some crops especially maize, zinc may affect cell mitosis, synthesis of food, tryptophan and protein development, and the activity of many enzymes, it also plays an essential role in the manufacturing of growth hormones and proteins. It is vital in chlorophyll synthesis and carbohydrate breakdown. In addition it is a necessary ingredient for calcium transfer all over the entire corn plant and also a component of various enzymes that are found in the synthesis of protein and the breakdown of nitrogen Marschner (2011).
Nitrogen is an important nutrient for plants and also an important factor that affects crop yield. It is one of the most important nutrients for corn growth. Balko and Russel (2000) reported that nitrogen fertilizer affects the quantity of corn cobs per plant and the length of corn cobs in different ways. The deficiency of nitrogen can distort certain metabolic functions in corn, which makes it the basis of plant growth and represents an important component of the plant's dry matter.

Phosphorus $(\mathrm{P})$ is the second most important nutrient after nitrogen, which allows high yields, especially corn, because plant products are often lacking and plants need them in relatively large quantities. The total concentration of $\mathrm{P}$ in crops generally ranges from 0.1 to 0.5 percent. Phosphorus is considered primarily a primary orthophosphate ion $\left(\mathrm{H}_{2} \mathrm{PO}_{4}^{-}\right)$, but some are also absorbed in the secondary form of orthophosphate $\left(\mathrm{HPO}_{4}\right)$. The late form increases with increasing soil $\mathrm{pH}$. Phosphates are an integral component of all living things. In plants, $\mathrm{P}$ is necessary for photosynthesis, respiration, cell functioning, gene transfer and reproduction. Without phosphorus, there are no cells, plants and grains, and without enough phosphorus, hunger is great (Ademba et al., 2015)

Potassium (K) is essential for all life forms of plants and animals. Potassium is one of the most important nutrients that is considered essential for growth and increased yield, although it is not part of the cell or the structural part of the plant. It is the richest cation in plants and is associated with many physiological processes that support the growth and development of plants. Water conditions, photosynthesis, assimilation and enzymatic activation can be influenced by potassium. Plants easily absorb the available soil K. Once inside the plant, the K can move. It moves slightly from the oldest tissue to the 
youngest tissue, so the symptoms of $\mathrm{K}$ deficiency appear in the older leaves. Potassium does not assume one of the chemical structural components of the plant. However, it remains intact as it affects the growth of the plant. Potassium stimulates root growth, strengthens stems, activates enzymes, regulates turbidity of plants, transports sugar and starch, promotes protein formation, regulates diseases and, in many other functions of plants, disease resistance, tolerance to water stress, involved in the development of grain. Almost all aspects of hardness and growth, development, performance and winter quality depend on the adequate supply of Potassium (John et al., 2016). Corn really needs potassium because it absorbs more potassium than any other element than nitrogen. It plays an important role in the growth of corn; Potassium is found only in soil in an inorganic form and has a profound effect on the synthesis of many organic components in plants. This is necessary in all metabolic processes of cells. This is especially important in the synthesis of carbohydrates (CHO), proteins, fats and oils, as well as in the translation of synthesized components and in the development of chlorophyll (Adia and Agba, 2015).

\section{Materials and Methods}

The experiment was conducted at the Soil Science research farm of the Sam Higginbottom University of Agriculture, Technology and Science Prayagraj (Allahabad) in Utter Pradesh during the 2017 and 2018 seasons in the karif. The area is located at latitudes $25^{0} 24$ '46, 14 'north latitude, $81^{0} 50^{\prime}$ ', longitude $81^{0} 0$ ' 49,91 'east longitude and $98 \mathrm{~m}$ above sea level. The treatments consisted of $0,369 \mathrm{~kg}$ of boron, copper, zinc per acre and 0,50 and $100 \mathrm{~kg}$ of nitrogen, phosphorus and potassium per hectare. Treatments were arranged in a completely randomized design and repeated four times. Soils samples for routine analysis were collected at depth of $0-15$, and $15-$ $30 \mathrm{~cm}$, from sites using bucket auger and shovel. Samples were, thoroughly, homogenized and treated as a single sample. The soils were dried in the laboratory, crushed using pestle and mortar and sieved through $2 \mathrm{~mm}$ sieve.

To ensure sowing, the experimental field was completely cleared of debris and other residues from previous crops, then it was ploughed by a tractor with a disk plough, and the land was then demarcated in to various plots ranging in size from 3 to 5 meters. A total of 36 plots have been prepared, the plots were thoroughly cleaned of stubble and levelled with a rake, and large crumbs of soil were thoroughly and systematically crushed and ground. An initial basic dose of fertilizer was used, in which furrows 4 to $5 \mathrm{~cm}$ deep were placed along the rows of seeds. The source of nutrients was urea, nitrogen, potassium, phosphorus, boron, zinc and copper. The treatments were divided into three parts, where the first part was used as basal application, while the second part was used when the plant height was at the knee stage and the last dose was applied at the flowering stage. The seeds were sown linearly. One seed was sown for every $25 \mathrm{~cm}$ between plants and $60 \mathrm{~cm}$ between rows, the seeds were drilled to a depth of $3-4 \mathrm{~cm}$.

\section{Results and Discussion}

Effects of boron, zinc, copper and npk on number of leaves in maize

The data on Tables 1 and 2 represent the effect of boron zinc copper and NPK on number of leaves in maize crop for the periods of 2017 and 2018 experimental seasons. In 2018 the maximum number of leaves recorded at 20DAS to 100DAS were $4.00,6.67,6.67,8.32$ and 8.33 , The numbers 
were obtained with the application of treatments T12 (100kg NPK + 9kg B,Zn $\left.\mathrm{Cu}, \mathrm{ha}^{-1}\right)$, T10 (100kg NPK + 3kg B, Zn $\left.\mathrm{Cu}, \mathrm{ha}^{-1}\right)$, T12 (100kg NPK + 9kg B, Zn $\left.\mathrm{Cu}, \mathrm{ha}^{-1}\right)$ and $\mathrm{T} 11(100 \mathrm{~kg} \mathrm{NPK}+6 \mathrm{~kg} \mathrm{~B}, \mathrm{Zn}$ $\mathrm{Cu}, \mathrm{ha}^{-1}$ ) while the lowest values of 3.27 , 4.00,4.67,6.32 and 6.00 were recorded from the control plot. In 2018there was some variation in the highest values recorded by the treatments, almost all the values were recorded with treatments $\mathrm{T} 12$ with the exception of 60DAS which was recorded with application of T11. The values are presented as follows 6.67, 9.67 8.33 9.33, and 10.33, while the least values of $4.67,6.00,4.67$, 4.62, and 5.00 were recorded from the control plots.

Most of the treatments show a significant effect on the plant $(\mathrm{P}<0.05)$, except at the early stage of growth which indicated a non significant effect (that is at 20 Days after sowing), this could be attributed to the fact that the uptake of nutrients at this period is not rapid and therefore not sufficient to show any effect on the plant, and this may be due to the fact that the roots of the crop were not fully developed to explore the nutrients surrounding the rhizosphere. The increased in number of leaves as recorded in this research is in conformity with the work of many research workers (Soomro et al., 2011; Bisnu et al., 2010 and Adiaha et al., 2015). They observed that the application of NPK, Boron, copper and zinc has the capacity to increase all the growth parameters of maize.

\section{Concentrations of nutrients in plant part}

\section{Nitrogen concentrations in stem of maize} (Zea mays L.)

The result presented on Table 3 show the concentration of nitrogen in stem of maize for the year 2017 trials. It is indicated that the highest concentrated of nitrogen $3.00 \mathrm{mg} / \mathrm{g}$ in the first year of the trial (2017) was recorded with treatments $100 \mathrm{kgNPK}+9 \mathrm{kgB} \mathrm{Zn,Cu} \mathrm{ha}{ }^{-}$ 1 , while the lowest concentration of $0.20 \mathrm{mg} / \mathrm{g}$ was recorded with control plots. The result recorded in that week of the trial shows a significant $(\mathrm{P}<0.05)$ effect of all the treatments. The result reveals that interaction between $\mathrm{B} \mathrm{Zn}, \mathrm{Cu}$ and NPK was significant. Similar observation was noted in the second year of the trial (2018) in which the highest Nitrogen concentration of $5.00 \mathrm{mg} / \mathrm{g}$ was recorded with treatments $100 \mathrm{kgNPK}+6 \mathrm{kgB}$ $\mathrm{Zn}, \mathrm{Cu} \mathrm{ha}{ }^{-1}$. While the second value of $3.5 \mathrm{mg} / \mathrm{g}$ was recorded with treatments $100 \mathrm{~kg}$ $\mathrm{NPK}+9 \mathrm{kgB} \mathrm{Zn,Cu} \mathrm{ha}{ }^{-1}$ and the lowest value of $0.10 \mathrm{mg} / \mathrm{g}$ was obtained with control plot. There was a significant difference among the treatments $(\mathrm{P}<0.05)$. Also the pooled mean data for the two years shows a significant $(\mathrm{P}<0.05)$ difference among the treatment.

The concentration of Nitrogen in the shoots of maize crop may be as a result of boron action which causes more nitrogen to be taking up from the soil medium through absorption. Similar observation was also discovered by Aref (2011); and Soomro et al., (2001). They noted that boron can influence the intake of nutrients from the growing medium and the accumulation by plant parts.

\section{Phosphorous concentration in shoots of maize (Zea mays L.)}

The result for the concentration of phosphorous (P) for the year 2017 is shown on table 4. As the result revealed the largest $P$ concentration $0.42 \mathrm{mg} / \mathrm{g}$ in the shoots was obtained with the treatment combination $100 \mathrm{kgNPK}+9 \mathrm{kgBCuZnha}^{-1}$ while the second largest concentration of $0.40 \mathrm{mg} / \mathrm{g}$ was recorded when $100 \mathrm{kgNPK}+6 \mathrm{kgBCuZnha}^{-1}$ was added. The lowest concentration of $\mathrm{P}$ $0.8 \mathrm{mg} / \mathrm{g}$ was registered with the control plot as indicated. There was a significant effect of treatments $(\mathrm{P}<0.05)$ as recorded within that 
week. Pooled mean data also indicated a significant influence of treatments (Table 5). In the second year (2018) of the research work, the maximum value of $\mathrm{P}$ concentration $5.00 \mathrm{mg} / \mathrm{g}$ was registered when $100 \mathrm{kgNPK}$ $+9 \mathrm{kgBCuZnha}^{-1}$ was added. The second maximum value of $\mathrm{P}$ concentration $1.51 \mathrm{mg} / \mathrm{g}$ is obtained with the addition of $100 \mathrm{kgNPK}$ $+6 \mathrm{kgB} \mathrm{Zn}, \mathrm{Cu} \mathrm{ha}^{-1}$. The control plot registered the minimum $\mathrm{P}$ concentration of $1.00 \mathrm{mg} / \mathrm{g}$ (Table 5). Significant difference $(\mathrm{P}<0.05)$ was also observed among the treatments so also is the pooled mean data which recorded significant difference. Studies have shown that many factors interact to play an important role in the accumulation of Phosphorous in part of maize according to the opinion of Pravin et al., (2013). They explain that genetic makeup and environmental influence has an important role in deciding the building up of $\mathrm{P}$ fertilizer in tissues of maize. Another observation by Muhammed et al., (2019) is that an interaction between boron and phosphorous in wheat resulted in increased in the yield of the crop this action will definitely lead to the gradual accumulation of phosphorous in plant tissue. A part from that observation the opinion of Pravin et al.,(2013) pointed out that genetic and environmental factor is one of the dormant reason that favor the concentration of $\mathrm{P}$ in maize.

\section{Potassium concentration in stem of maize (Zea mays L.)}

The result presented on Table 4 is showing the concentration of Potassium in shoots of maize for two years. In 2018 the maximum concentration of $\mathrm{P} 4.00 \mathrm{mg} / \mathrm{g}$ was determined with the addition of $100 \mathrm{kgNPK}+9 \mathrm{kgB} \mathrm{Zn}$, $\mathrm{Cuha}^{-1}$ the second maximum concentration of $\mathrm{P} \quad 3.00 \mathrm{mg} / \mathrm{g}$ was encountered when $100 \mathrm{kgNPK}+6 \mathrm{kgB} \mathrm{Zn}, \mathrm{Cu} \mathrm{ha}^{-1}$ was incorporated into the soil. The least concentration of $1.00 \mathrm{mg} / \mathrm{g}$ was recorded with the untreated plot. The statistical analysis show a significant difference among the treatments, similar observation was noticed in the second year of the experiment with the addition of treatments $100 \mathrm{kgNPK}$ $+9 \mathrm{kgBCuZn} \mathrm{ha}^{-1}$ recording the maximum concentration of $6.00 \mathrm{mg} / \mathrm{g}$ while the second concentration value of $5.00 \mathrm{mg} / \mathrm{g}$ was recorded with treatments $100 \mathrm{kgNPK}+6 \mathrm{kgB}$ $\mathrm{Zn}, \mathrm{Cu} \mathrm{ha}{ }^{-1}$. The result recorded a significant difference among the treatments $(\mathrm{P}<0.05)$. Similarly the pooled mean result also show a significant effect $(\mathrm{P}<0.05)$ of the difference. Krzystof et al., (2016) note that NPK has accumulated in some parts of maize crop treated with many different concentrations of fertilizer input. Similar reports were also noted by the following Monica and Tadeus (2010). The ongoing researchers explain that the accumulation of potassium in the shoot may be a result of the depth at which the manure is left in the soil, which is ideal for root absorption and subsequent translocation to the shoot. The same phenomena were noticed during this work, which is when the fertilizer was added to the plow layer the roots of the plant were able to use them properly and transport them into the shoot, Shaimaa et al., (2014) reported that Boron increase the concentration of potassium in Tomato leaves including tissue concentration of Nitrogen and calcium. This shows that boron can also increase the concentration of these nutrients in other crops.

\section{Concentration of nitrogen in leaves of maize (Zea mays)}

The information on Table 3 is showing the result of Nitrogen concentration of maize leaves for the year 2018 and 2019 experimental periods. Base on that in 2018 the concentration of Nitrogen varies from $0.10 \mathrm{mg} \mathrm{kg}^{-1}$. $1.76 \mathrm{mg} / \mathrm{kg}$ and $1.75 \mathrm{mg} \mathrm{kg}^{-1}$, they were recorded by the control plots and treatments $100 \mathrm{kgNPK}^{2}+9 \mathrm{kgBkgha}^{-1}$; and 
$100 \mathrm{kgNPK}+3 \mathrm{kgB} \mathrm{Zn,} \mathrm{Cu} \mathrm{ha}{ }^{-1}$. The results recorded for that year shows a significant $(\mathrm{P}<0.05)$ effect of the treatment and also a significant interaction between them. In the second year of the trial that is in 2019, the concentration recorded varies from $1.10 \mathrm{mg}$ $\mathrm{kg}^{-1} ; 1.91 \mathrm{mg} \mathrm{kg}^{-1}$ and $1.90 \mathrm{mg} \mathrm{kg}^{-1}$. They were obtained from the control plots and application of treatments $100 \mathrm{kgNPK}+9 \mathrm{kgB}$ $\mathrm{Zn}, \mathrm{Cu} \mathrm{ha}^{-1}$ and $100 \mathrm{kgNPK}+3 \mathrm{kgB} \mathrm{Zn}$, $\mathrm{Cu} \mathrm{ha}{ }^{-1}$. The result recorded in the second year followed the same track with that of the first trial. The pooled mean data for the first and second experiment indicated a significant difference among the treatments. The results for the two trials shows that the concentration of Nitrogen in leaves of maize is above the levels of deficiency limit as categorized by Mills and Jones (1996). The accumulation of Nitrogen as observed in this work can be due to the positive action of boron which is being executed on nitrogen which gradually encourages the absorption of the nutrients from the soils. Adams et al., (2011) recorded an increased in the concentration of nitrogen in leaves of maize when the fertilizer boron was added to the soils, not only that other nutrients were also increased. This clearly demonstrated one of the synergistic influences of the fertilizer boron on other nutrients. Similarly Adiloglu and Sevin (2011) also recorded increased in the concentration of Nitrogen in maize when boron was use as a source of fertilizer during their investigation.

\section{Response of Boron, Zinc Copper and NPK on total yield of Grain and Stover of Maize}

The information shown on (Table 5) is showing the response of applying Boron, Zinc Copper and NPK on total yield of maize in 2017 and 2018 experimental seasons. In 2017 the data recorded ranges from 64.34t/ha; 64.12.12t/ha; and 26.80t/ha, which were recorded with treatments $100 \mathrm{kgNPK}$
$+9 \mathrm{kgBZnCu} \mathrm{ha}{ }^{-1} ; 100 \mathrm{kgNPK}+6 \mathrm{kgB} \mathrm{Zn} \mathrm{Cu}$ $\mathrm{ha}^{-1}$ and the control plot. The data shows a significant difference among the result for the period under investigation there was also a significant $(\mathrm{P}<0.05)$ interaction between the nutrients. In the second year of the research in 2018 the result ranges from 64.43t/ha; $64.31 \mathrm{t} / \mathrm{ha}$ and $26.99 \mathrm{t} / \mathrm{ha}$ they were recorded by treatments $100 \mathrm{kgNPK}+9 \mathrm{kgB} \mathrm{Zn,} \mathrm{Cu} \mathrm{ha}{ }^{-1}$; $100 \mathrm{kgNPK}+6 \mathrm{kgB} \mathrm{Zn,} \mathrm{Cu} \mathrm{ha}{ }^{-1}$ and the control plot. The information also stated that there was a significant $(\mathrm{P}<0.05)$ difference between the treatments. Also a significant interaction between the treatments was also observed, likewise the pooled mean data for the two years also depicted a significant $(\mathrm{P}<0.05)$ difference between the treatments.

The increased in yield of maize crop has been documented by some authors (Adrian et al., 2016; Sharma, 2003 and Hussaini et al., 2006), almost all the authors cited attributed the increased in yield as a result of the influence of the fertilizers added especially Nitrogen and Phosphorous. It is believed that Nitrogen is involved in photosynthesis and other related physiological process in plant while phosphorous is also important in development of roots; the presence of phosphorous will assist in the uptake of nitrogen and some of the other micronutrients whose activities may help in yield production. Boron which is added plays a role in seed development and in uptake and transfer of water for seed production, Zinc may interact with boron to accelerate grain production (Sinha et al., 2000) while copper as reported by Ernest el al., (2014) encourages production and assist in increase of tissues content of maize. Therefore the combination of NPK, Boron, zinc and copper couple with the conducive physical soil properties of the experimental field it is therefore possible to get a favorable yield of maize from this research. 
Table.1 Effects of boron zinc copper and NPK on number of leaves 2017

\begin{tabular}{|c|c|c|c|c|c|}
\hline Treatments & 20 DAS & 40 DAS & 60 DAS & 80 DAS & 100 DAS \\
\hline $\mathbf{T}_{\mathbf{1}}$ & 3.27 & 4.00 & 4.67 & 6.32 & 6.00 \\
\hline $\mathbf{T}_{\mathbf{2}}$ & 4.00 & 4.67 & 5.00 & 6.63 & 6.67 \\
\hline $\mathbf{T}_{\mathbf{3}}$ & 4.33 & 4.00 & 5.00 & 6.33 & 6.33 \\
\hline $\mathbf{T}_{\mathbf{4}}$ & 4.00 & 4.00 & 5.33 & 6.37 & 7.33 \\
\hline $\mathbf{T}_{\mathbf{5}}$ & 3.33 & 4.33 & 5.67 & 7.00 & 6.67 \\
\hline $\mathbf{T}_{\mathbf{6}}$ & 3.67 & 6.00 & 6.33 & 6.67 & 7.00 \\
\hline $\mathbf{T}_{\mathbf{7}}$ & 4.00 & 4.33 & 6.34 & 6.33 & 7.00 \\
\hline $\mathbf{T}_{\mathbf{8}}$ & 3.67 & 5.67 & 6.00 & 6.33 & 7.00 \\
\hline $\mathbf{T}_{\mathbf{9}}$ & 3.33 & 5.67 & 5.67 & 7.00 & 7.00 \\
\hline $\mathbf{T}_{\mathbf{1 0}}$ & 3.33 & 6.67 & 5.67 & 7.33 & 7.33 \\
\hline $\mathbf{T}_{\mathbf{1 1}}$ & 3.67 & 6.00 & 5.67 & 8.33 & 8.33 \\
\hline $\mathbf{T}_{\mathbf{1 2}}$ & 4.00 & 5.00 & 6.67 & 7.33 & 7.33 \\
\hline F- test & $\mathrm{NS}$ & $\mathrm{S}$ & $\mathrm{S}$ & $\mathrm{S}$ & $\mathrm{S}$ \\
\hline S. Ed. (土) & 0.355 & 0.434 & 0.432 & 0.408 & 0.352 \\
\hline C. D. (P= 0.05) & 0.724 & 0.885 & 0.880 & 0.834 & 0.717 \\
\hline
\end{tabular}

Table.2 Effects of boron zinc copper and NPK on number of leaves 2018

\begin{tabular}{|c|c|c|c|c|c|}
\hline Treatments & 20 DAS & 40 DAS & 60 DAS & 80 DAS & 100 DAS \\
\hline $\mathbf{T}_{\mathbf{1}}$ & 4.67 & 6.00 & 4.67 & 4.67 & 5.00 \\
\hline $\mathbf{T}_{\mathbf{2}}$ & 5.33 & 8.00 & 5.33 & 5.67 & 5.67 \\
\hline $\mathbf{T}_{\mathbf{3}}$ & 6.00 & 7.67 & 5.00 & 5.00 & 4.67 \\
\hline $\mathbf{T}_{\mathbf{4}}$ & 5.67 & 7.00 & 5.00 & 5.67 & 5.00 \\
\hline $\mathbf{T}_{\mathbf{5}}$ & 5.33 & 6.33 & 5.67 & 5.67 & 5.67 \\
\hline $\mathbf{T}_{\mathbf{6}}$ & 5.67 & 7.67 & 6.00 & 6.00 & 6.00 \\
\hline $\mathbf{T}_{\mathbf{7}}$ & 5.67 & 6.67 & 6.34 & 7.33 & 7.33 \\
\hline $\mathbf{T}_{\mathbf{8}}$ & 6.67 & 8.34 & 7.67 & 6.67 & 6.67 \\
\hline $\mathbf{T}_{\mathbf{9}}$ & 6.00 & 7.67 & 7.00 & 7.00 & 7.67 \\
\hline $\mathbf{T}_{\mathbf{1 0}}$ & 6.57 & 7.33 & 7.67 & 8.00 & 8.33 \\
\hline $\mathbf{T}_{\mathbf{1 1}}$ & 6.00 & 8.33 & 8.33 & 9.00 & 10.00 \\
\hline $\mathbf{T}_{\mathbf{1 2}}$ & 6.67 & 9.67 & 7.33 & 9.33 & 10.33 \\
\hline $\mathbf{F}-\mathbf{t e s t}$ & $\mathrm{NS}$ & $\mathrm{S}$ & $\mathrm{S}$ & $\mathrm{S}$ & $\mathbf{S}$ \\
\hline $\mathbf{S . ~ E d . ~} \mathbf{(} \mathbf{(})$ & 0.222 & 0.441 & 0.227 & 0.294 & 0.350 \\
\hline C. D. $(\mathbf{P}=\mathbf{0 . 0 5})$ & 0.454 & 0.900 & 0.463 & 0.006 & 0.715 \\
\hline
\end{tabular}


Table.3 Concentration of nitrogen in shoots and leaves F maize (Zea mays L.)

\begin{tabular}{|c|c|c|c|c|c|c|}
\hline \multirow{2}{*}{$\begin{array}{r}\text { Treatments } \\
\qquad \mathbf{T}_{1}\end{array}$} & \multicolumn{2}{|c|}{$\begin{array}{ll}2017 & 2018 \\
\text { SHOOT } & \end{array}$} & \multirow{2}{*}{$\begin{array}{c}\text { Pooled data } \\
0.10\end{array}$} & \multicolumn{2}{|c|}{$\begin{array}{cr}2017 & 2018 \\
& \text { LEAVES }\end{array}$} & \multirow{2}{*}{$\begin{array}{c}\text { Pooled data } \\
1.10\end{array}$} \\
\hline & 0.10 & 0.10 & & 0.10 & 0.10 & \\
\hline $\mathbf{T}_{2}$ & 0.20 & 0.20 & 0.20 & 1.70 & 1.10 & 1.40 \\
\hline $\mathbf{T}_{3}$ & 1.00 & 0.30 & 0.65 & 1.70 & 1.20 & 1.45 \\
\hline $\mathbf{T}_{4}$ & 1.25 & 0.50 & 0.88 & 1.30 & 1.30 & 1.30 \\
\hline $\mathbf{T}_{5}$ & 1.25 & 2.00 & 1.63 & 1.50 & 1.60 & 1.55 \\
\hline $\mathbf{T}_{6}$ & 1.20 & 3.00 & 2.10 & 1.60 & 1.50 & 1.55 \\
\hline $\mathbf{T}_{7}$ & 1.25 & 4.00 & 2.63 & 1.65 & 1.60 & 1.63 \\
\hline $\mathbf{T}_{8}$ & 1.25 & 4.00 & 2.63 & 1.70 & 1.50 & 1.60 \\
\hline $\mathbf{T}_{9}$ & 1.40 & 4.00 & 2.70 & 1.64 & 1.80 & 1.77 \\
\hline$T_{10}$ & 1.50 & 4.00 & 2.75 & 1.75 & 1.90 & 1.83 \\
\hline$T_{11}$ & 2.00 & 3.00 & 3.50 & 1.67 & 1.80 & 1.74 \\
\hline $\mathbf{T}_{12}$ & 3.00 & 5.00 & 3.50 & 1.76 & 1.90 & 1.95 \\
\hline F- test & S & $\mathrm{S}$ & S & S & S & S \\
\hline S. Ed. ( \pm$)$ & 0.0057 & 0.006 & 0.0057 & 0.0297 & 0.0236 & 0.025 \\
\hline C. D. $(P=0.05)$ & 0.011 & 0.012 & 0.012 & 0.0483 & 0.0483 & 0.05067 \\
\hline
\end{tabular}

Table.4 Concentration of potassium and phosphorous in shoots of maize (Zea mays L.)

\begin{tabular}{|c|c|c|c|c|c|c|}
\hline \multirow{2}{*}{$\begin{array}{l}\text { Treatments } \\
\qquad \mathbf{T}_{1}\end{array}$} & \multicolumn{2}{|c|}{$\begin{array}{cc}2017 & 2018 \\
& \text { PHOSPHOROUS }\end{array}$} & \multirow{2}{*}{\begin{tabular}{|c|} 
Pooled data \\
0.55 \\
\end{tabular}} & \multicolumn{2}{|c|}{$\begin{array}{cr}2017 & 2018 \\
& \text { POTASSIUM }\end{array}$} & \multirow{2}{*}{$\begin{array}{c}\text { Pooled data } \\
0.57 \\
\end{array}$} \\
\hline & 0.10 & 1.00 & & 1.00 & 0.14 & \\
\hline $\mathbf{T}_{2}$ & 0.10 & 1.25 & 0.68 & 1.00 & 1.00 & 1.00 \\
\hline $\mathbf{T}_{3}$ & 0.10 & 1.25 & 0.68 & 1.00 & 1.00 & 1.00 \\
\hline $\mathbf{T}_{4}$ & 0.10 & 1.49 & 0.80 & 1.00 & 1.00 & 1.00 \\
\hline $\mathbf{T}_{5}$ & 0.20 & 1.25 & 0.73 & 3.00 & 3.00 & 3.00 \\
\hline $\mathbf{T}_{6}$ & 0.20 & 1.50 & 0.85 & 3.00 & 3.00 & 3.00 \\
\hline $\mathbf{T}_{7}$ & 0.30 & 1.50 & 0.90 & 3.00 & 4.00 & 3.50 \\
\hline $\mathbf{T}_{8}$ & 0.20 & 5.00 & 2.60 & 4.00 & 4.00 & 4.00 \\
\hline $\mathbf{T}_{9}$ & 0.40 & 3.00 & 1.70 & 4.00 & 4.00 & 4.50 \\
\hline$T_{10}$ & 0.40 & 3.00 & 1.70 & 3.00 & 4.00 & 4.00 \\
\hline$T_{11}$ & 0.30 & 3.00 & 1.65 & 3.00 & 5.00 & 4.00 \\
\hline $\mathrm{T}_{12}$ & 0.40 & 3.00 & 1.70 & 4.00 & 6.00 & 4.50 \\
\hline F- test & NS & S & $\mathrm{S}$ & S & $\mathrm{S}$ & $\mathrm{S}$ \\
\hline S. Ed. ( \pm$)$ & 0.0093 & 0.0077 & 0.0083 & 0.0111 & 0.0099 & 0.0103 \\
\hline C. D. $(P=0.05)$ & 0.0183 & 0.0157 & 0.0017 & 0.0203 & 0.0203 & 0.0213 \\
\hline
\end{tabular}


Table.5 Effect of B, $\mathrm{Zn} \mathrm{Cu}$ and NPK on grain yield and stover of maize (Zea mays L.)

\begin{tabular}{|c|c|c|c|c|c|c|}
\hline \multirow{2}{*}{$\begin{array}{c}\text { TREATMENTS } \\
\qquad \mathrm{T}_{1}\end{array}$} & \multicolumn{2}{|c|}{$\begin{array}{ll}2017 & 2018 \\
\text { Stover } & \text { yield }\end{array}$} & \multirow{2}{*}{$\begin{array}{l}\text { Pooled } \\
\text { Data } \\
54.38\end{array}$} & \multicolumn{2}{|c|}{$\begin{array}{lr}2017 & 2018 \\
\text { Grain } & \text { Yield }\end{array}$} & \multirow{2}{*}{$\begin{array}{l}\begin{array}{l}\text { Pooled } \\
\text { Data }\end{array} \\
64.39\end{array}$} \\
\hline & 44.34 & 64.43 & & 26.80 & 26.99 & \\
\hline $\mathbf{T}_{2}$ & 54.12 & 66.31 & 60.22 & 49.52 & 49.71 & 64.22 \\
\hline $\mathbf{T}_{\mathbf{3}}$ & 56.57 & 66.75 & 61.66 & 36.57 & 36.75 & 36.66 \\
\hline $\mathbf{T}_{4}$ & 56.80 & 76.99 & 66.89 & 48.40 & 26.99 & 26.90 \\
\hline $\mathbf{T}_{5}$ & 44.34 & 68.15 & 58.06 & 37.97 & 38.15 & 38.06 \\
\hline $\mathbf{T}_{6}$ & 54.12 & 81.42 & 66.33 & 31.24 & 31.42 & 31.33 \\
\hline $\mathbf{T}_{7}$ & 56.57 & 92.40 & 72.31 & 42.22 & 42.40 & 42.31 \\
\hline $\mathbf{T}_{8}$ & 56.80 & 100.38 & 80.29 & 40.19 & 40.38 & 40.29 \\
\hline $\mathbf{T}_{9}$ & 46.11 & 76.29 & 61.20 & 46.11 & 46.29 & 46.20 \\
\hline $\mathbf{T}_{10}$ & 53.40 & 63.59 & 58.49 & 43.40 & 43.59 & 43.50 \\
\hline $\mathbf{T}_{11}$ & 79.52 & 89.71 & 64.57 & 64.12 & 64.31 & 64.12 \\
\hline $\mathbf{T}_{12}$ & 80.40 & 108.59 & 64.45 & 64.34 & 64.43 & 64.34 \\
\hline F- test & $S$ & $S$ & $\mathrm{~S}$ & $\mathrm{~S}$ & $S$ & $S$ \\
\hline S. Ed. ( \pm$)$ & 0.4887 & 0.527 & 0.5053 & 0.4887 & 0.523 & 0.5053 \\
\hline C. D. $(P=0.05)$ & 0.9997 & 1.067 & 1.316 & 0.9967 & 1.0677 & 1.0316 \\
\hline
\end{tabular}

Stover yield of maize crop is depicted on Table 5. As indicated from the data on the table the highest Stover yield of 80.40 in 2017 was recorded with the application of treatments100kgNPK $+9 \mathrm{kgBZnCu}^{-1}$, this is closely followed with 79.52 which was recorded with treatments $100 \mathrm{kgNPK}+6 \mathrm{kgB}$ $\mathrm{Zn} \mathrm{Cu} \mathrm{ha}{ }^{-1}$ while the lead stover yield 44.34 was obtained from the control plots, There was a significant $(\mathrm{P}<0.05)$ difference among the treatments and also significant interaction difference among the treatments was also observed. In 2018 there was a wide difference in the result recorded it was little bit higher than the previous cropping seasons. Maximum value recorded was 108.89 with the application of treatments $100 \mathrm{kgNPK}$ $+6 \mathrm{kgB} \mathrm{Zn} \mathrm{Cu} \mathrm{ha}{ }^{-1}$ this is followed by 106.38 which was obtained with the application of treatments $50 \mathrm{kgNPK}+9 \mathrm{kgB} \mathrm{Zn} \mathrm{Cu} \mathrm{ha}{ }^{-1}$ while the least value of 64.43 was recorded with the control plot. There was a significant $(\mathrm{P}<0.05)$ difference among the treatments also a significant interaction exist between the treatments, The pooled mean data of the two years period also recorded a significant difference between the two years (Table 5).

The increased in Stover yield of maize has been related to the steady supply of fertilizer which leads to enhanced use of the various nutrients by the maize crop, as result of that there is increased in nutrients uptake by grain and Stover and this will gradually affect other growth parameters, Ramanjneyulu et al., (2018).

The following researchers Arakadiusy and Katarzyna (2016) and Gustaro et al., (2016) also indicated that copper, boron, zinc and NPK are capable of increasing dry matter production, nutrients accumulation and yield in corn and wheat. While in another observation Kayode et al., (1985) reported that the addition of macronutrients and micronutrient singly or combined has been 
noted to significantly and continually increased the yield of maize. Also Nurul et $a l$. , (2014) discovered that application copper alone increases grain production in corn. The outcome of this work is in agreements with the explanation of the quoted research workers.

Summary and conclusion are as follows:

A field experiment was carried out for two consecutive years (2018 and 2019) growing seasons at the research farm of department of soil science and agricultural chemistry Sam Higgins Bottom University of Science Technology and Agriculture Prayagraj to investigate the Effect of Boron, Zinc, Copper and NPK on Physical and chemical property of soil and uptake by maize (Zea mays L.) plant. The experiment was laid in a completely randomized design experiment consisting of three replications of three levels of boron, zinc, copper $(0,3,6$ and $9 \mathrm{mg} / \mathrm{kg} \mathrm{B})$ and three levels of NPK $(0,50$, and $100 \mathrm{~kg} / \mathrm{ha})$ all replicated three times. The Soil samples were analyzed for $\mathrm{pH}$, EC, Organic carbon, organic matter, total nitrogen, phosphorous, potassium, boron, zinc, copper and exchangeable bases. Plant parameters measured and analyzed comprised of plant height, number of leaves, and number of cobs. Others include dry matter production, concentration of boron, zinc copper and npk in leaves, shoots and grains. Also investigated was the efficiency between Soil application of boron and foliar application of boron Result obtained indicated that application of boron, zinc copper and NPK significantly $(\mathrm{P}<0.05)$ influenced plant growth yield and quality parameters of maize (Zea mays L.). The highest values of plant height recorded at 80DAS to 100DASwere recorded by 100kgNPK+9Kg B, Zn Cu ha ${ }^{-1}$ application. Boron, zinc copper, nitrogen, phosphorous and potassium application significantly influences the maize parameters relating to growth, yield and quality of maize. Significant difference among treatment effects was found on the growth response of maize plants, and maximum yields were recorded with $100 \mathrm{kgNPK}+9 \mathrm{Kg} \mathrm{B}, \mathrm{Zn} \mathrm{Cu} \mathrm{ha}{ }^{-1}$ and $50 \mathrm{~kg} \mathrm{NPK}+6 \mathrm{~kg} \mathrm{~B}, \mathrm{Zn}, \mathrm{Cu} \mathrm{ha}{ }^{-1}$. The plant was able to respond to the levels of various treatments applied, there was also a considerable increased in the yield quality of the grains and stover of maize due to proper utilization of the applied nutrients by the plan

\section{References}

Arakadaiusy, S., and Katarzyna, W. 2016. Effect of folia application of $\mathrm{Cu}, \mathrm{Zn}$ and $\mathrm{Mn}$ on Yield and quality indicators of winter wheat grain Chelean J. Agric Res. Vol 76(2):0718-5839.

Adrian, G., Viorel, I., Arin, D., Georgeta, T., Lenuta, I. and Dumitrus, S. 2016. Grain yield and yield component of maize under different preceding crops and Nitrogen Condition, Agriculture and Agricultural Science Procedia 10(2016) 104-111.

Aref, F. 2011. Zinc and boron content by maize leaves from soil and foliar application of zinc sulfate and boric acid in zinc and boron deficient soils. Middle-East J. Sci. Res. 7(4): 610-618.

Arshadullah, M., A. Ali., I. A. Mahmood, A. Amir and M. Salim. 2010. Effect of graded level of boron on paddy yield under salt-affected soils. Abstract: $13^{\text {th }}$ Congress of Soil Sci. Faisalabad, Pakistan, Pp. 22-27.

Adams, G.N., Zamehin, A., Aslihan, E. and Metin, T. 2011. Yield and chemical composition of maize as affected by boron management.

Ademba J.K. Kwach, AO. Esilaba and M. Ngari. 2015. The Effects of Phosphate Fertilizers and Manure on Maize Yields in South Western Kenya, East African." Agricultural journal and Forestry 81:1, 1-11.

Adiaha, M.S., and Agba, O.A. 2015. Influence of different Method of Fertilizer 
application on the Growth of Maize for increased Production in South Nigeria. September Friday, 2015. http:www.world scientific news.com.

Adiloglu, A., and Sevin, A. 2011. Effect of Boron application on the growth and nutrient content of maize plant. Research journal of agriculture and Biological Science, 2(1) 1-4.

Aydn, A., Kant, C. and Ataoglu, N.2005. Effect of boron and phosphorus application on the growth and mineral content of corn on Ezzurum and Rice soils. Ziraat Fakultesi Dergisi, Universitedi 125-129.

Adediran, J. A and Banjoko, V. A., 2003. Comparative Effectiveness of Some Compost Fertilizer Formulation for Maize In Nigeria. Nigerian Journal of Soil Science, (13): 42-48

Anthony, R., Patrick, V., Thomson, P. 2002. The World Health Report. 2002: Reducing risks, promoting healthy life. World Health Organization, Geneva, pp: 346-348.

Balko, L.G., and Russel, W.A., 1980. Effect of rate of different inbred line and hybrid lines and hybrid progeny. Prediction of yield response. Maydica 25-79

Bishnu, H., Jiban, S., and Bandhu, R.B. 2010. Effect of micronutrients on growth band productivity of Maize in Acidic Soil." International Journal of Applied and Basic Sciences 8-1.

Brady, N.C. and Weil, R.R. 1999. The Nature and Properties of Soils. 12th Edition, Prentice Hall Publishers, London, 1-9, 453-536, 727, 739-740.

Blevins D.G. and Lukaszewski K.M., 1998. Boron in plant structure and function. Annu. Rev. Plant. Physiol. Plant. Mol. Biol. 49: 481-500.

Chaudhary, D.P., Ashwani, K., Sapna, S., Mandhana, P. and Kumar R.S. 2012. Maize as fodder, An alternative approach, Director of Maize Research, Pusa Campus, New Delhi-11001. Technical Bulletin 2012/04 PP 32.

Cakmak, I., Sari, N., Marschner, H., Kalayci, M., Yilmaz, A., Eker, S., Gulut, K.Y.
1996. Dry matter production and distribution of zinc in bread and durum wheat genotypes differing in zinc efficiency. Plant Soil. 180, 173-181.

Durbak A.R., Phillips K.A., Pike S., O’Neill M.A., Mares J., Gallavotti A., Malcomber S.T., Gassmann W., McSteen P. 2014. Transport of boron by the tasselless 1 aquaporin is critical for vegetative and reproductive development in maize. Plant Cell 26: 2978-2995

Érica de, O. A., Elcio Ferreira, D. S., and Marcos, A. C. 2018. Boron-zinc interaction in the absorption of micronutrients by cotton. Agronomía Colombiana. 36(1), 51-57

Fisher, R.A. 1956. In Statistical methods for research workers, by Oliver and Boyd, 356. Edinburgh: Q.J.R. Meteorol soc.,

Fageria, N. K. Baligar, V. C. and R. B. Clark, 2002. Micronutrients in Crop Production, Vol. 77, Advances in Agronomy, New York, NY, USA

Fageria, N. and L. Kumar, 2002. Influence of micronutrients on dry matter yield and interaction with other nutrients in annual crops. Pesquisa Agropecuária Brasileira, 37: 1765-1772.

FAO. (2007). Food and Agriculture Organisation yearbook Volume 60 .

Fashina, A.S., K.A. Olatunji and K.O. Alasiri, 2002. Effect of different plant populations and poultry manure on the yield of Ugu (Telfairia occidentalis) in Lagos State, Nigeria. Proceedings of the Annual Conference of Horticultural Society of Nigeria, May14-17, NIHORT, Ibadan, Nigeria.

Gustavo, A. S., Gaspar, H.K. and Hamilton, S. P., 2016. Methods of adding micronutrients to a NPK formulation and maize development, Journal of Plant Nutrition, 39:9, 1266-1282, DOI: https://doi.org/10.1080/01904167.2015.1 087569.

Gurpreet.K., and Kelly.A.N. 2015. Effect of foliar Boron fertilization of fine textured soils on corn yield. Journal agronomy, 5, $1-18$ 
Gittinger, J. P. 1982. Economic analysis of agricultural project (2nd ed.). Baltimore: John Hopkins University Press.

Genc, Y., McDonald, G. K., Graham R. D. 2006. Contribution of different mechanisms to zinc efficiency in bread wheat during early vegetative stage. Plant Soil. 281, 353-367.

Hussain N., Khan A. Z., Akbar H., Akhtar S. 2006. Growth factors and yield of maize as influenced by phosphorus and potash fertilization. Sarhad J. Agric. 22 579583.

Hansen B, Schjønning P, Sibbesen E. 1999. Roughness indices for estimation of depression storage capacity of tilled soil surfaces. Soil and Tillage Research; 52: 103-111. DOI: $10.1016 /$ S01671987(99)00061

IITA. 2013. International Institute for Tropical Agriculture. Growing maize in Nigeria, Information and Communication Support for Agricultural Growth in Nigeria. USAID Pp 1-8.

Iken, N.A, and Amusa. J.E. 2014. Maize Research and Production in Nigereria. Institute of Agricultural land Training, OAU, PMB 5029 Moor Plantation, PP. 302-307. Ibadan, Nigeria.

Joshi, P.K., Singh. N.P., Sing. N.N., Gerpacio. R.V., and Pingali. P.L., 2005. Maize in India, Production systems, constrains and research Prioritic. Mexico. D.F.,

Jain A, P. Smith, A.P., Nagarajan, V.K., Lahner, B., Meagher, R.B., Raghothama, K.G., 2009. Variations in the composition of gelling agents affect morphophysiological and molecular responses to deficiencies of phosphate and other nutrients. Plant Physiol 150: 1033-1049.

John, L, H., Samuel, L.T., Warner, L.N and James, D.B. 2016. Soil Fertility and Fertilizers An Introduction to Nutrient Management Pearson India Education Services Pvt.Ltd.

Jones, J. 2001. Laboratory guide for conducting soil tests and plant analysis. Boca Raton, Fl.: CRC Press
Krzysztof, B., Renata, G., and Anna, B. 2016. Accumulation of Nitrogen, Phosphorus and Potassium in mature Maize under variable ratesof mineral fertilization Fragm. Agron. 33(1), 7-19

Kayode,G., and Akinola, O. 1985. Macro and Micronutrients effects on yield and nutrients concentrations of maize (Zea mays L..) in Southw west Nigeria. Research 8: 129135 west junk publishers Dordrecht printed in Netherlands.

Lindsay, W.L.; Norvell, W.A.1978. Development of a DTPA soil test for zinc, iron, manganese, and copper. Soil Science Society of America Journal 42: 421-428.

Muhammad, Z., Muhammad, Y., Tanveer, A., Muhammad, N., Adam, M., Yasir, H. 2019. Folir application of micronutrients enhances crop stand, yield and the biofortification essential for human health of different wheat cultivars. 18 (6):1369137

Manasa, L. P., and Devaranavadagi, S. B. 2015. Effect of foliar application of micronutrients on growth, yield and nutrient uptake of maize. Karnataka $J$. Agric Sci., (28): 474-476

Muhammad, T., Aseghar, A., Farhan, K., Muhammad, N. and Nacem, F.A. 2012. Boron Application on Growth Yield and quality of Maize." Pak. J. Sci. Ind. Res. Bio. Sci, 117-121.

Monika, S., and Tadeusz, F. 2010. accumulation of Nitrogen and Phosphorus by Maize as the result of a reduction in the Potassium fertilization rate, Ecological chemistry and engineering. vol 17(1) 84-88.

Monni, S., M. Salemaa and N. Millar, 2000. The tolerance of Empetrum nigrum to copper and nickel. Environmental Pollution, 109: 221-229.

Morelli, E. and G. Scarano, 2004. Copperinduced changes of non-protein thiols and antioxidant enzymes in the marine microalga Phaeodactylum tricornutum. Plant Science, 167: 289-296.

Mathad, P. and H. Pratima, 2009. Copper toxicity causes oxidative stress in Brassica juncea L. seedlings. Indian 
Journal of Plant Physiology, 14: 397-401.

Marschner, H. 2011. Mineral Nutrition of Higher Plants, Academic Press, New York, NY, USA,

Mwendera EJ, Feyen J. 1993. Predicting tillage effects on infiltration. Soil Science. 155: 229-235.

Mills, H.A. and Jones Jr., J.B. 1996. Plant Analysis Handbook II. A Practical Sampling, Preparation, Analysis, and Interpretation Guide. Micro-Macro Publishing, Athens

Nurul, S., Sarwar, J., Mohammad, M., Khandaker, M., Mohd, K., Mohd, N., and Mohd, H. 2014. Application of Copper Increased Corn Yield Through Enhancing Physiological Functions. Aust. J.Basic \& Appl. Sci., 8(16): 282-286

Navoday. S., Heralal. B., Suresh.C., Hareram, K., Manisha, J., and Upendar K., 2018. Effect of Foliar Spray of Micronutrients on Uptake of Micronutrients in (Solanum esculemntum Mill

Navyashree, M.R., Ravi, M.V., Narayana, R.K., Vioyarathi, G., Yadahalli. 2014. Effect of Sulphur, Zinc and Boron on growth and yield of rainfed maize." International journal of Agriculture, National Academy of Agric Science, 3441- 3743.

Nayak, A.K., Bhattacharyya, P., Shahid, M., Tripathi, R., Lal, B., Gautam, P., Mohanty, S., Kumar, A., and Chatterjee, D. 2016. Modern Techniques in Soil and Plant Analysis. Kalyani Publishers, New Delhi, 110002; pp. 272.

Nable, R.O., Bañuelos, G.S., and Paull, J.G., 1997. Boron toxicity. Plant Soil 198: 181-198.

Ramanjineyulu, M., Srinivasa, M., Ramesh, P.V., and Kavitha, P.2018. Effect of secondary and micronutrients on uptake, mobilization and partitioning of nutrients from source to sink in maize hybrid. The Pharma Innovation Journal. 7(6): 396400

Oertli, J. J. and Richardson, W. F. 1970. The mechanisms of boron immobility in plants. Physiologia Plantarum, 23, 108.

Obi, C.O., Nnabude, P.C., and Onucha,
E.2005. Effect of kitchen wastes compost and tillage on soil chemical properties and yield of okra (Albemoschus esculentus). Nig. J. Soil Sci., 15: 69-76.

Pravin, R. C., Dodha, V. A., Vidya, D. A., Manab, C., and Saroj, M. 2013. Soil Bulk Density as related to Soil Texture, Organic Matter Content and available total Nutrients of Coimbatore Soil International Journal of Scientific and Research Publications, Volume (3): I2, 2250-3153

Panhwar, Q.A., Radziah, O., Kharif, Y.M. and Naher, U.A. 2011. Application of boron and zinc in tropical soil and its effect on maize growth and soil microbial environment. Australian J. Crop Science., 5(12):1649-1654

Rajna, D., Washu, D., Shazia, B., Nawaz, K., Shabana, M., and Ghulam, H.,2016. Boron application using optimizing dose and time through foliar application for enhancing yield of wheat Sci. Int. (Lahore), 28(4), 4039-4042

Rengel, Z., Graham, R.D. 1995. Importance of seed $\mathrm{Zn}$ content for wheat growth on $\mathrm{Zn}$ deficient soil. Plant Soil. 173, 259-266.

Shaimaa, A., Abo, H., and Soad, S., 2014. Effect of Boron on Growth and Some Physiological Activities of Tomato Plant. Life Science Journal Research, 11(3): 3240.

Sarkaut, N., Salaheddin, M., and Ahmed, S. 2013. Growth and yield response of maize to different rate of potassium and boron International journal of Agriculture and crop sciences, Pp. 222-670.

Shaghloli, S., Nemati, N., and Silpur, M, 2011. Effect of nitrogen fertilizer and the spray of Boron elemen. Some agronomic traits of maize hybrid (SC704). Anals of Biological Research, (3): 32-40.

Saeed, N., Hussain, M. and Saleem, M. 2002. Interactive effect of biological sources and organic amendments on the growth and yield attributes of sunflower (Helianthus annuus L.), Pakistan Journal of Agricultural Sciences, vol-39(2), pp. 135-136. 
Shanti, K.P., Rao, M.R., Reddy, M.S., Sarma, R.S. 2000. Response of maize (Zea mays) hybrid and composite to different level of nitrogen." Indian Journal of Agricultural Science. Vol 67, 424 -425.

Sherchan, D.P., Upreti, R. and Massey, S.L. 2003. Effect of micronutrients on production of Maize in the acid Soils of Chitwan Valley." International center for integrated mountain Development Kathmandu, Nepal. Kathmandu: Quality printers Kathmandu, Nepal, 169.

Soomro, Z. H. Baloch, P. A., and Gandhai, A. W., 2011. Comparative effect of foliar and soil applied boron on growth and fodder yield of maize. Pak J. Agric Eng. Vet Sci, 77(1)18-26.

Sunil, K., Dinesh, K., Sekhon, K., and Parkash, C. 2011. Influence of Levels and Methods of Boron Application on the Yield and Uptake of Boron by Cotton in a Calcareous Soil of Punjab Communications in Soil Science and Plant Anal https://doi.org/10.1080/ 00103624.2018.1431268

Shakeel, A. A., Muhammad, F.S., Muhammad, S. A., Muhammad. Safeer, Imran, K., A. 2017. Dynamics of Soil and Foliar Applied Boron and Zinc to Improve Maize Productivity and Profitability.
Pakistan Journal of Agric Research Vol (3) 3:294-302

Stefano, P., Dris, R and Rapparini, F., 2004. Influence of Growing Conditions on Yield and Quality of Cherry. II Fruit. Journal of Agriculture and Environment, (2): 307-309.

Sharma, S. P. and Subehia S. K. 2003. Effects of twenty-five years of fertilizer use on Maize and wheat yields and quality of an acidic soil in the western Himalayas Expl Agric.), volume 39, pp. 55-64. Cambridge University Press, DOI: 10.1017/S001447970200103

Singh, J. P., D. J. Dahiya and R. P. Narwal, 1990. Boron uptake and toxicity in wheat in relation to zinc supply. Fertilizer Research, 24: 105- 110.

Warrington, K. (1923). The effect of boric acid and borax on the broad bean and certain other plants. Ann. Bot., 37, 629-672.

Yruela, I., 2009. Copper in plants: acquisition, transport and interactions. Functional Plant Biology, 36: 409-430.

Yruela, I., 2005.Copper in plants. Brazilian Journal of Plant Physiology, 17: 145-156.

Zegu, T 2010. Plant physiology. Sundersland, Mn and kenel Wt: Sinauer Associates.

\section{How to cite this article:}

Bubarai, M.L., T. Thomas and Swaroop, N. 2020. Response of Boron, Copper, Zinc Nitrogen, Phosphorus and Potassium on Some Growth Qualities of maize (Zea mays L.) Plant. Int.J.Curr.Microbiol.App.Sci. 9(08): 2382-2396. doi: https://doi.org/10.20546/ijcmas.2020.908.273 